\title{
Impulse Purchase in iTV Advertising: a Conceptual Model of Gap Analysis
}

\author{
Azizah Che Omar \\ School of Technology \\ Multimedia and \\ Communication, \\ Universiti Utara Malaysia
}

\author{
Norshuhada Shiratuddin \\ School of Technology \\ Multimedia and \\ Communication, \\ Universiti Utara Malaysia
}

\author{
Siti Mahfuzah Sarif \\ School of Technology \\ Multimedia and \\ Communication, \\ Universiti Utara Malaysia
}

\begin{abstract}
Numerous studies have been carried out to find out the factor of impulse purchase components in different environment such as on website, mobile, traditional retail store and traditional television. However, those studies are not dedicated to design models to increase impulse purchase on iTV advertising. Therefore, an analysis involving five existing models of website advertising environment, three models on traditional television advertising and four models from iTV advertising were carried out. It is revealed that the conceptual design models of iTV advertising that specifically focus on impulse purchase is highly scarce, suggesting a gap that ought to be looked into.
\end{abstract}

\section{Keywords}

t-commerce, interactive TV advertising, impulse purchase.

\section{INTRODUCTION}

The marketing team in many companies realizes the importance of impulse purchase phenomenon in traditional commerce, which allows the marketers to attract customers in many ways such as store position products, store promotion, product packaging in an enticing way to increase impulse purchase, and getting consumers to be impulsive [3].

In addition, recently various studies find the factors of impulse purchase in different domain such as website, mobile, traditional retail store and traditional television. However, most of them are not dedicated to design models to increase impulse purchase on iTV advertising that specifically focus on television commerce (t-commerce).

In fact, some design elements and guidelines that should be considered when developing the iTV advertising for tcommerce impulse purchase are not clearly identified in the existing models. This article provides literatures analysis on iTV advertising, t-commerce, and impulse purchase. The aim is to identify research gap of the iTV advertising model.

\section{2. iTV ADVERTISING}

Traditional TV advertising is less efficient and a revised interactive advertising model is required to commercialize the content on TV [4]. The traditional TV advertising uses push model, where advertisers send information to passive and non-interactive viewers [5]. On the contrary, interactive advertising in iTV is based on the original pull model, where the viewers have active access to the contents and active interaction with the services, where they are able to purchase or receive the information requested for specific goods via remote control [6].
On top of that, iTV advertising allows users to have two-way communication by sending or requesting additional information back to the advertiser or programmer. It also could convert the medium of TV from a passive to an active involvement in order to encourage viewers to do purchasing and having interaction with the TV screen [7]. Other than that, iTV also provides new opportunities for advertisers to increase the effectiveness of TV advertising messages for interactive advertising [8]. Additionally, iTV advertising provides audiences with new sales channels and gives higher return to the advertisers [1]. It is the most suitable method in promoting services and products since it provides a medium with ease of use, more efficient, high visibility, and could give viewers more enjoyment to watch.

There are different types of interactive advertising to attract viewer's attention and provide with specific information. According to NDS Business Consulting [9], interactive advertising can be categorized into response, jump, tag, incentive, targeted, viewer response, and impulse purchase. Impulse purchase can influence and allow the viewers to purchase on the spot without planning [10]. By understanding the consumer behavior and environmental psychology, it will easily influence users to make purchases and access the products or services.

Through the years, impulse purchase has also been made easier by innovations, such as telemarketing, debit cards, and credit cards. In the last decade, rapid developments in information technology have substantially changed the landscape of consumer behavior. The retailing availability for the Internet has brought about an increase impulse purchase [11]. Consequently, impulse purchase accounts for a large volume of product sales every year contributing to $\mathrm{t}$ commerce [12].

For t-commerce, consumers' buying opportunities will be expanded for an increased ease to make purchases and increased accessibility to products and services. Additionally, t-commerce will eliminate the constraints in terms of space and time that are always experienced by shoppers in the context of traditional commerce [13]. Goods and services are purchased easily on TV using a remote control instead of a telephone, PC, or PDA [14]. In fact, in the Europe and USA it was found that the successful of t-commerce adoption was excellent, where $46 \%$ of the consumers are happy and interested in services provided by t-commerce [31]. 


\section{T-COMMERCE}

According to $\mathrm{Yu}$ et al. [14] t-commerce is electronicallymediated commerce over digital iTV. T-commerce may involve purchase orders via TV by clicking through with the TV remote control. Development of services on iTV enables it to become an e-commerce medium merging voice, video, and data transactional, and combines the interactivity of the Internet with high quality TV video [15]. T-commerce is expected to change the style of an individual's purchasing and to create new business opportunities for providers. There are two types of t-commerce application [14], which are homeshopping and homebanking. Homeshopping allows viewers to purchase products directly on TV. Meanwhile, homebanking allows viewers to check their balance and account status on TV.

Development of iTV Service allows it to be a medium for ecommerce that combines video, audio, and data to make commercial transactions (t-commerce), and combine the interactivity of the Internet with high-quality TV video [15].

A conceptual model for t-commerce was proposed byGhisi [16] which outlines three main characteristics: presentation, form of payment, and content associatively. T-commerce presentation relates to content of sales channel, program related, interactive advertising, and other initiatives. The way of payment consists of payment by credit card, direct debit, and other forms. In addition, there are two types of services related to $\mathrm{TV}$ content which are contextualized and independent. However, this model does not include consumer behavior regarding impulse purchase.

\section{IMPULSE PURCHASE}

Several researchers have proposed variety of definitions of impulse buying. As an example, Rook [17]defined it as an unplanned purchase, which happens when a consumer experiences positive effects when exposed to a stimulus. Later, Piron [18] integrated the definition and proposed a new comprehensive definition of impulse buying. Particularly, it contains four characteristics which are suggestion, reminder, pure, and unplanned impulse buying.

Suggestion impulse purchase occurs when a consumer sees a product and tries to visualize the need for it [19]. Meanwhile, reminder impulse purchase occurs when a consumer is reminded to purchase the product when he or she sees it [19].

Pure impulse purchase occurs when a consumer purchases products impulsively. The consumer may remember about running out of that product or may still remember an advertisement about the interest of item, which sparks the impulse purchase. On the contrary, unplanned impulse buying occurs when consumers do not plan to do any purchasing, but search for and take advantage of promotions in the market [19]. The common link across these different types of impulse purchase is that the purchase is a result of an exposure to the stimulus [18]

A few researchers have studied impulse purchase behavior for different requirements. Dholakia [13] proposed one of the most detailed theoretical frameworks that explains the impulse buying process. Meanwhile, Dittmar, Beattie, and Friese [20] explained why consumers purchase products impulsively and Adelaar, Chang, Lancendorfer, Lee, and Morimoto [21] studied on how media formats have an influence on impulse buying intentions. However, these previous researches do not include how impulse purchase occurs in iTV advertising that specifically focus on tcommerce context.

\section{IDENTIFICATION OF RESEARCH GAP}

There has been an obvious necessity to examine the factors influencing individuals to purchase product on television shopping program, however research effort on this is minimal [10]. One such factors, the impulse purchase behavior has been studied for different domains such as traditional retail store [22], online shopping [23], website [24] and Promotional TV Program [10]. However, those studies are not dedicated to design models to increase impulse purchase on iTV advertising

For the reasons discussed above, this study is looking into three environments of advertising; the web, traditional TV and interactive $\mathrm{TV}$ in order to identify the gap pertinent to consumer behavior in purchasing impulsively on iTV. Table 1 lists five of advertising models in the web environment.

Table 1. Studies of impulse purchase in website advertising

\begin{tabular}{|c|c|c|c|}
\hline No & Sources & Description & Limitations \\
\hline Web1. & $\begin{array}{l}\text { Conceptual Framework of } \\
\text { Website Attributes in } \\
\text { Online Purchase [24] }\end{array}$ & $\begin{array}{l}\text { This model comprise of three } \\
\text { components; website cues, } \\
\text { personality traits, and impulse } \\
\text { purchase. } \\
\text { It adhere the environmental } \\
\text { psychology of Stimulus-- } \\
\text { Organism-Response framework } \\
\text { to interpret impulse purchase. } \\
\text { - The adapted theories hierarchy of } \\
\text { effect model and persuasion } \\
\text { knowledge model. } \\
\text { This model investigate how the } \\
\text { website cues (products } \\
\text { availability,website ease of use } \\
\text { and visual appeal) affect } \\
\text { personality traits (instant } \\
\text { gratification, normative } \\
\text { evaluation and impulsiveness) to } \\
\text { urge the impulse purchase online. }\end{array}$ & $\begin{array}{l}\text { - The provided elements discuss more } \\
\text { on how website cues might affect } \\
\text { impulse purchase behavior on } \\
\text { website but not on television. } \\
\text { The target user is online consumer on } \\
\text { website not and not appropriate for } \\
\text { television user. } \\
\text { This model only provides components } \\
\text { to be considered during designing } \\
\text { website advertising, but not the specific } \\
\text { component to develop iTV advertising. }\end{array}$ \\
\hline
\end{tabular}


Web2. Conceptual Framework of Website Brand Equity [25]
- This model consists of three components; website brand equity, customer perceive value, and online purchase intention.

- The model adapts theory of the Stimulus-Organism-Response paradigm and brand equity theory development.

- Theory of persuasion knowledge model and hierarchy of effect model are adapted in the model.

- The model focuses on how website brand equity influences customer tobe impulsively.
- $\quad$ The provided elements illustrate more on how brand equity might influence customer purchase intention on website but not on television.

- $\quad$ This model only provides components to be considered during designing website advertising, but not the specific component to develop iTV advertising.

\begin{tabular}{ll}
\hline Web3. & Model of Website \\
& Aesthetics within Online \\
& Environment [26]
\end{tabular}

Web4. Conceptual Framework Effect of Atmospherics on Online Shopping [27]
- This model consists of four components; website aesthetics, perceived ease of use and perceived usefulness, intention to purchase and actual purchase.

- This model stress on the impact of Web site aesthetics that enable online retailers to design Web sites that engage users, leading to additional purchases.

- This model identifies the effects of website aesthetics which contains web site color, images and typography on impulse buying tendency.
- The provided elements discuss more on how website aesthetic might influence user toward impulse purchase on website but not on television.

- The target user is participant from social media outlet but not television user.

- $\quad$ Some design elements and guidelines that should be considered when developing the iTV advertising towards impulse purchase are not clearly identified in this model.
- This model consists of three components; atmospherics, emotions and approach or avoidance behavior.

- The adapted approach is environmental psychology that operationalized in a StimulusOrganism-Response framework.

- The elaboration likehood model and conditioning theory are adapted in the model.

- This model adapts environmental psychology that suggeststhe stimuli have antecedents affect on consumers' emotional states (organism), whose response may result in impulse purchase behaviors (responses).
Web5. Conceptual Model of

Media Format on

Behavioral Intention [21]
- This model consists of three components; media format, emotional response and buying intent.

- The adapted theory is environmental psychology, elaboration likelihood model, conditioning theory, recursive model, and business model.

- The model stress on how media format might influence impulse buying in website.
- The provided elements discuss more on how environmental psychology of the website might influence user toward impulse purchase on website but not on television.

- Some design elements and guidelines that should be considered when developing the iTV advertising towards impulse purchase are not clearly identified in this model. 
Moreover, the design models of impulse purchase on television environment as listed in Table 2 shows more components of impulse purchase on traditional television advertising compared to iTV advertising. Additionally, the models also do not provide specific design elements to increase impulse purchase on iTV advertising specifically for t-commerce. In relation to this, the design model for tcommerce proposed by Ghisi, Lopes, and Siqueira [16] also does not include consumer behaviour regarding impulse purchase.

Table 2. Studies of impulse purchase in traditional television advertising

\begin{tabular}{|c|c|c|c|}
\hline No. & Sources & Description of model & Limitation \\
\hline TV1. & $\begin{array}{l}\text { Conceptual Model for } \\
\text { Effect TV Display on } \\
\text { Impulse Purchase [28] }\end{array}$ & $\begin{array}{l}\text { - It focuses on how promotional TV } \\
\text { display influence male and } \\
\text { female's behaviors for impulse } \\
\text { shopping. } \\
\text { - The adapted theory is theory of } \\
\text { affective and cognitive psychology } \\
\text { processes, theory of planned } \\
\text { behavior, and theory of consumer } \\
\text { behavior and persuasion knowledge } \\
\text { model. }\end{array}$ & $\begin{array}{l}\text { It includes television viewers as part of } \\
\text { the user but not focus on iTV user. } \\
\text { Although this model provides } \\
\text { components to be considered during } \\
\text { designing television advertising but it is } \\
\text { not very comprehensive to provide } \\
\text { guideline to the advertising designer to } \\
\text { develop iTV advertising. } \\
\text { Lack of clarification in terms of each of } \\
\text { the multimedia features to point the iTV } \\
\text { viewer as part of the user. }\end{array}$ \\
\hline TV2. & $\begin{array}{l}\text { Model of Impulse } \\
\text { Buying Tendency } \\
\text { Toward Television } \\
\text { shopping [29] }\end{array}$ & $\begin{array}{l}\text { - This model focuses on effects of } \\
\text { perceived parasocial interactions, } \\
\text { perceived social involvement, and } \\
\text { perceived loneliness on mood, } \\
\text { and mood's consequent influence } \\
\text { on perceived risk toward impulse } \\
\text { buying tendency. } \\
\text { - This study focuses on middle age } \\
\text { and older female television home } \\
\text { shoppers. } \\
\text { - Persuasive theory had been adapted } \\
\text { as a guideline to develop the } \\
\text { model. }\end{array}$ & $\begin{array}{l}\text { The provided elements discuss on how } \\
\text { persuasive strategies might influence } \\
\text { user toward impulse purchase on } \\
\text { traditional advertising but not } \\
\text { interactive advertising. } \\
\text { It includes television viewers as part of } \\
\text { the users but not iTV users. } \\
\text { Although this model provides } \\
\text { components to be considered during } \\
\text { designing television advertising but it is } \\
\text { not very comprehensive to provide } \\
\text { guideline to the advertising designer to } \\
\text { develop iTV advertising. }\end{array}$ \\
\hline TV3. & $\begin{array}{l}\text { Conceptual model of } \\
\mathrm{t} \text {-commerce [16] }\end{array}$ & $\begin{array}{l}\text { - This model consists of three } \\
\text { elements; presentation, form of } \\
\text { payment and content } \\
\text { associatively. }\end{array}$ & $\begin{array}{l}\text { - The model describe the component of t- } \\
\text { commerce however the model does not } \\
\text { have component of impulse purchase. } \\
\text { The provided elements in the model do } \\
\text { not have specific design on development } \\
\text { of iTV advertising toward Impulse } \\
\text { Purchase. }\end{array}$ \\
\hline
\end{tabular}

In addition, the models that focus interactive television advertising as listed in Table 3 describe more on the characteristics of iTV advertising different with traditional TV advertising. Furthermore, the element provided are not dedicated to design models to increase impulse purchase on iTV advertising [32]; [33]; [34] and [35].Therefore, such a gap ought to be investigated which could contribute to the fields of business and interactive advertising.

Table 3. Studies of advertising model on interactive television (iTV)

\begin{tabular}{|c|c|c|c|}
\hline No. & Sources & Description of model & Limitation \\
\hline iTV1. & $\begin{array}{l}\text { An On-Demand } \\
\text { Advertising Model for } \\
\text { Interactive Television } \\
\text { [32] }\end{array}$ & $\begin{array}{l}\text { The model consists of interactive } \\
\text { elements such as bookmarking } \\
\text { the product, notification, } \\
\text { exploring product vault, and } \\
\text { product information. } \\
\text { The research prototype demonstrate } \\
\text { how product information could be } \\
\text { integrated into programming } \\
\text { content and how product } \\
\text { information could be indexed for } \\
\text { more user friendly, personalized } \\
\text { and effective advertising. }\end{array}$ & $\begin{array}{l}\text { These studies are not focus on dedicated } \\
\text { to design models to increase impulse } \\
\text { purchase on iTV advertising. } \\
\text { Poorly discuss on characteristics } \\
\text { interactivity platform of iTV advertising. } \\
\text { The model does not clearly define the } \\
\text { impulse purchase elements to be } \\
\text { embedded in the iTV advertising design } \\
\text { component. } \\
\text { This model does not provide clear } \\
\text { procedure in developing iTV advertising. }\end{array}$ \\
\hline
\end{tabular}


- The research prototype uses remote control and navigation through number of keys.

\begin{tabular}{lll}
\hline iTV2. $\begin{array}{l}\text { ANew Content- } \\
\text { Related Advertising } \\
\text { Model For Interactive } \\
\text { Television [33] }\end{array}$ & $\begin{array}{l}\text { This model suggest interactive } \\
\text { advertising model that uses a TV } \\
\text { program. }\end{array}$ \\
& $\begin{array}{l}\text { The study investigates the } \\
\text { efficiency of systems, the level of } \\
\text { user satisfaction and the behavior } \\
\text { through an experiment, a survey } \\
\text { and an interview. } \\
\text { This research provides a number of } \\
\text { clues that can improve user } \\
\text { experience with interactive } \\
\text { advertising using interfaces and } \\
\text { related content. } \\
\text { By categorizing the ads provided in } \\
\text { the experiment, the most popular } \\
\text { type of interactive advertising was } \\
\text { determined. } \\
\text { In this paper, a new advertising } \\
\text { model that uses interactivity and the } \\
\text { internet connectivity of television is } \\
\text { proposed. }\end{array}$
\end{tabular}

- The model provides elements that can improve user experience with interactive advertising using interfaces and related content.

- However the provided elements do not emphasis much on impulse purchase elements.

- This study also is not dedicated to design model to increase impulse purchase on iTV advertising.

- The provided elements in the model do not have specific design on development of iTV advertising.

- This model does not include theory of advertising and consumer behavior.

- Some design elements and guidelines that should be considered when developing the iTV advertising towards impulse purchase are not clearly identified in this model.

\begin{tabular}{ll}
\hline iTV3. & Context Aware \\
& Personalized Ad \\
& Insertion in an \\
& Interactive TV \\
& Environment [34]
\end{tabular}

iTV4. Intreractive trend in the TV advertising lanscape [35]
- This model proposed architecture for context aware real time selection and insertion of advertisements into the live broadcast stream by taking into consideration the user's current and past contextual information.

- The project also involves development of intelligent iTV applications such as user identification, intent tracking, personalized ad insertion etc.

- This model consists of XML based MPEG 7 DDL along with TV Anytime Metadata Specification are used as a representation format for metadata to represent and describe components of the system.
- The model focus more on the architecture for context aware insertion of advertisement into the live broadcast stream.

- However the provided elements do not emphasis much on impulse purchase elements.

- Some design elements and guidelines that should be considered when developing the iTV advertising towards impulse purchase are not clearly identified in this model.

- This model does not include theory of advertising and consumer behavior.

- The provided elements in the model do not have specific design on development of iTV advertising.
- This research focus on the trends in the interactive TV advertising landscape, the new television ecosystem features and its impact in the TV advertising market.

- The research emerging interactive advertising models centered whether on television or supported by additional equipment (tablets and smartphones as secondary screens).

- It propose a taxonomy regarding the advertising models in this new TV ecosystem (centred on the TV-set and on the secondary screen).
- The model describes the emerging interactive advertising models centred whether on television or supported by additional equipment (tablets and smartphones as secondary screens), however the component provided do not emphasize on impulse purchase elements.

- This study also not dedicated to design model to increase impulse purchase on iTV advertising.

- Some design elements and guidelines that should be considered when developing the iTV advertising towards impulse purchase are not clearly identified in this model.

- This model does not include theory of advertising and consumer behavior. 


\section{GAP ANALYSIS}

Table 4 shows the importantcomponents in studying the concept of impulse purchase for iTV advertising; (1) element of interactive advertising, (2) impulse purchase elements, and (3) advertising theory.From the analysis, it is found that models from website advertising and traditional TV advertising include the impulse purchase elements which can be embedded in the iTV advertising design. In addition, models from website advertising and interactive television alsoconsist of interactive advertising elements that can be considered as a guideline to develop a design model for iTV advertising. Furthermore, the advertising theory that apply on website and traditional television advertising also can be used as a guideline in developing iTV advertising towards impulse purchase.

Table 4. Analysis of elements included inthe studied models

\begin{tabular}{c|c|c|c}
\hline Models & $\begin{array}{c}\text { Interactive } \\
\text { Advertising } \\
\text { elements }\end{array}$ & $\begin{array}{c}\text { Impulse } \\
\text { Purchase } \\
\text { elements }\end{array}$ & $\begin{array}{c}\text { Advertising } \\
\text { Theory }\end{array}$ \\
\hline Web1 & $\sqrt{ }$ & $\sqrt{ }$ & $\sqrt{ }$ \\
Web2 & & $\sqrt{ }$ & $\sqrt{ }$ \\
Web3 & $\sqrt{ }$ & $\sqrt{ }$ & $\sqrt{ }$ \\
Web4 & & $\sqrt{ }$ & $\sqrt{ }$ \\
Web5 & $\sqrt{ }$ & $\sqrt{ }$ \\
\hline TV1 & & & \\
TV2 & & & \\
TV3 & & & \\
\hline iTV1 & $\sqrt{ }$ & & \\
iTV2 & $\sqrt{ }$ & & \\
iTV3 & $\sqrt{ }$ & & \\
iTV4 & & & \\
\hline
\end{tabular}

Figure 1 summarizes the gap from the three different sources which are from website advertising, traditional TV advertising, and iTV advertising. From the analysis, it is found that models from website advertising and traditional TV advertising include the impulse purchase elements. However those impulse purchase elements are not present in iTV advertising [16]; [32]; [33]; [34] and [35]. Therefore, in order to develop a model for iTV advertising that encapsulates the impulse purchase elements, the elements of impulse purchase from the website and traditional TV advertising will be referred to as a basis to this study. In addition, the elements of interactive advertising from website and interactive television could be embedded as well in the proposed model.

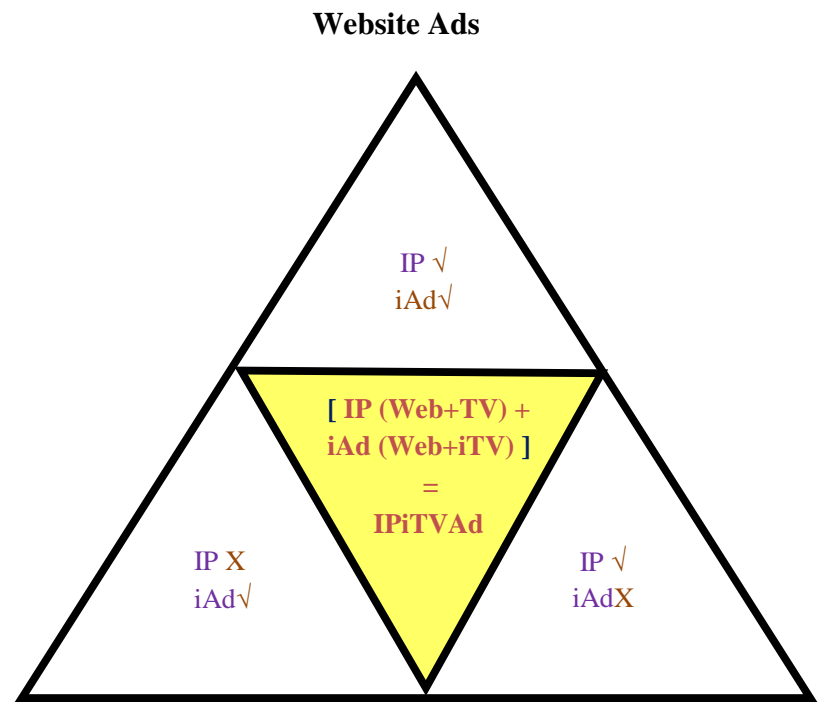

iTV Ads

Traditional TV Ads

Fig 1: Research gap summarization

Note:
$\sqrt{ } \quad-$ Include
$\mathrm{X}-$ Does not include
$\mathrm{IP} \quad-$ Impulse Purchase
iAd - Interactive Advertising
Web - Website
$\mathrm{TV}-$ Television
iTV - Interactive television
IPiTVAd - Impulse Purchase in interactive television
advertising

\section{CONCLUSION}

The iTV advertising has more attractions that the traditional $\mathrm{TV}$, simply because it makes viewers feel more enjoyment through flexibility of its interaction and the vividness of its presentations. This study believes that by adding impulse purchase elements in iTV advertising, it will increase the power of purchasing among viewers and perhaps will expand economy growth of the nation. Besides that, the study of impulse purchase brings more benefits to the advertiser to reach the target market by understanding more about consumer behavior. In relation to this, it will also help them to plan good marketing strategies and develop effective advertisement in a systematic way. Hence, this study will focus on the development of conceptual design model of iTV advertising that consist of impulse purchase elements. 


\section{ACKNOWLEDGMENTS}

The authors wish to thank Universiti Utara Malaysiaand Ministry of Education Malaysia for sponsoring this study.

\section{REFERENCE}

[1] Television Advertising Survey. 2011. Datacenter. Retrieved from http://adage.com/datacenter/globalmarketers2011 Unregulated On-Line Buying. Journal of ComputerMediated Communication, 6:3.

[2] Deloitte. 2011. TV Shopping 2011. Perspectives on television in words and number. Retrieved from http://www.deloitte.com/view/en_GB/uk/industries

[3] Dholakia, U.M. 2000. Temptation and Resistance: An Integrated Model of Consumption Impulse Formation and Enactment. Psychology \& Marketing, 17:11, 955982.

[4] Interactive Advertising Bureau, IAB. 2011. An Interactive Advertising Overview. Retrieved from http://www.iab.net/media/file/iTVCommitteeWhitePaper v7.pdf

[5] Vennou, P., Mantzari.E., \& Lekakos, G. 2009 Evaluating Program-embedded Advertisement Format in Interactive Digital TV. Proceeding of EuroITV'9, Leuven, Belgium.

[6] Kelly, K., \& Wolf, G. 1997. PUSH! Kiss your browser goodbye: the radical future of media beyond the Web. Wired, Retrieved from http://www.wired.com/wired/archice/5.03/ff_push.html

[7] Kingsford, I. 2003. Interactive TV Advertising: Turning Viewers Into Direct Leads Without A Set-Top Box. Retrieved from www.broadcastpapers.com

[8] Giotis, P., \& Lekakos, G. 2009. Effectiveness of Interactive Advertising Presentation Models. In Proceedings of EuroITV'09, Leuven, Belgium

[9] NDS Business Consulting. 2000. Interactive Advertising Broadcast. Retrieved from http://www.broadcastpapers.com/ data/NDSInteractiveAD01.tm

[10] Park, J., \& Lennon, S. J,"Psychological and environmental antecedents of impulse buying tendency in the multichannel shopping context". Journal of consumer Marketing, 2006.

[11] Madhavaram, S.R. \& Laverie, D.A, "Exploring Impulse Purchasing on the Internet", Advances in Consumer Research, 2004, 31, 59-66.

[12] Hausman, A, "A Multi-Method Investigation of Consumer Motivations in Impulse Buying Behavior", Journal of Consumer Marketing, 2000, 17:5, 403-419.

[13] Eroglu, S. A., Machleit K. A., \& Davis L. M, 2001"Atmospheric Qualities of Online Retailing: A Conceptual Model and Implications", Journal of Business Research, 2001, 177-184.

[14] Yu, J., Ha, I., Choi, M., \& Rho, J., 2005. Extending the TAM for a TCommerce, Information \& Management, 965-976.

[15] Simon, Y., \& Shim, Y.J. 2002, Interactive TV: VoD meets the Internet, Computer 35(7).

[16] Ghisi, B.C., Lopes, \& G.F., Siqueira. 2009. Conceptual Model for T-Commerce in Brazil. Federal University, Santa Catarina. Brazil
[17] Rook, D. W, “The Buying Impulse”,Journal of Consumer Research,1987, 189-199

[18] Piron, F,"Defining Impulse Purchasing"Advances in Consumer Research, 1991, 18, 509-514.

[19] Stern, H, "The Significance of Impulse Buying Today", Journal of Marketing, 1962, 26:2, 59-62.

[20] Dittmar, H., Beattie, J., \& Friese, S. 1996. Objects, Decision Considerations and Self-Image in Men's and Women's Impulse Purchases. Acta Psychologica, 187206.

[21] Adelaar, T., Chang, S., Lancendorfer, K.M., Lee, B., \& Morimoto, M, "Effects of Media Formats on Emotions and Impulse Buying Intent",Journal of Information Technology, 2003, 247-266.

[22] Beatty, S. E., \& Ferrell, M. E, "Impulsive Buying: Modeling Its Precursors",Journal of Retailing, 1998, 169-191.

[23] Kwek, C.H, Tan, H.P, \& Lau, T.C, "Investigating the Shopping Orientations on Online Purchase Intention in the e-Commerce Environment: A Malaysian Study", Journal of Internet Banking and Commerce,2010, vol 15 , no. 2

[24] Liu, Y., Li, H., \& Hu, F. 2013. Website attributes in urging online impulse purchase: An empirical investigation on consumer perceptions. Decision Support Systems, 55(3), 829-837. doi:10.1016/j.dss.2013.04.001

[25] Fan, X., Tian, X., \& Xiao, S. 2012. A Study on the Operation Mechanism of Website Brand Equity Based on S-O-R Paradigm. IEEE, (1994).

[26] Bono, J. 2012. The Influence of Web Site Aesthetics on Impulse Purchase Behavior within Online Retailing Environments. PhD Thesis.

[27] Koo, D.-M., \& Ju, S.-H, "The interactional effects of atmospherics and perceptual curiosity on emotions and online shopping intention",Computers in Human Behavior, 2010, 26(3), 377-388 doi:10.1016/j.chb.2009.11.009

[28] Sadia, Q. 2007. Effect of TV displays on impulse purchase. Master Dissertation, 0-63.

[29] Lee, M. S. 2008. Television shopping: the effect of persuasive strategies on parasocial interaction, subjective well-being, and impulse buying tendency among older women. Dissertation Master.

[30] Brown, I., Rijk, K. D., Patel, K., Twum-Ampofo, Y., \& Belle, J.P. 2006. T-Commerce: an Investigation of NonAdoption in South Africa. Proceeding of CISTM, Chandigarh, India.

[31] Digisoft. 2004. T-Commerce. Retrieved from http://www.digisoft.tv/products/tcommerce.html

[32] Erdogan, E. 2004. An On-Demand Advertising Model for ITV. Master Thesis. Georgia Institute of Technology

[33] Jae Hoon, C., Young Jun, S., \& Junghee, Ry. 2008. A New Content-Related Advertising Model. IEEE.

[34] Thawani, A., Gopalan, S. \& Sridhar, V. 2004. Context aware personalized Ad insertion in an interactive TV environment. Paper presented at the workshop of Personalization in Future TV, Eindhoven the Netherlands.

[35] Almeida, P., Abreu, J.,Reis, M., \& Cardoso. M.2013. Interactive Trends in the TV Advertising Lanscape, In conference on ENTERprise Information Systems. 